\title{
マグロの筋肉骨格構造に由来する尾鯺の力学的特性
}

\section{Mechanical Characteristics of Caudal Fin Resulting from Caudal Muscle-Skeletal Structure of Blue Fin Tuna}

\author{
O栗田周治（信州大院） 正 森川裕久（信州大） 正 小林俊一（信州大）
}

Shuji KURITA, and, Shinshu University, 3-15-1 Tokida, Ueda, Nagano Hirohisa MORIKAWA, Shunichi KOBAYASHI, Shinshu University

Key Words: Caudal fin, Fin ray, Flexural rigidity, Young's modulus, Tuna

\section{1. はじめに}

一般に,生物の構造と運動は高機能高性能であると考えられる. 現在に至るまで水棲生物は長い年月をかけて環境に応じた多種多 様な推進形態に進化してきた. そこで，水棲動物の運動，推進機 構を模倣した推進体に関する研究が行われている. その中に高速 魚の尾鯺の動きを模倣した推進用振動翼に関する研究がある. 我々は高速魚であるマグロの尾鰭による推進方法に着目し，マグ ロの尾鱪の形状, 翼の変形挙動についての調查を行い, そこで得 られた知見をもとに振動翼推進に関する研究を行ってきた ${ }^{1)}$. 本 研究では, 実際のマグロの尾鯺の力学的特性を求め, それに基づ いて模型翼を作製し振動翼推進装置による実験を行い，その翼挙 動と推進特性の関係を明らかにすることを目的としている. 今回 は, マグロの尾鰆の力学的特性について報告する.

\section{2. 実験装置および実験方法}

尾鱪の力学的特性を調べるための曲げ試験装置の概略図を Fig.1に示す. 荷重は荷重棒により与え, 尾鰭の変位はレーザー変 位計(KEYENCE,LC-2100)により測定する. 荷重棒, レーザー変位 計，そして尾鯺を固定するテーブルを移動させることにより，任 意の点に荷重を加えることができ，また任意の点の変位を測定す ることができる.

測定箇所を Fig. 2 に示す. 尾鯺を鯺条方向に 4 等分し体軸の方

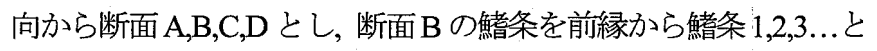
した. 断面 $\mathrm{A}$ の位置で固定し, 断面 $\mathrm{B}$ の任意の鱪条に荷重を加え, 断面 B の位置におけるすべての鯺条の変位を計測し, 荷重点の鯺 条を変化させ, 同様にすべての鯺条の変位を測定した. 断面 B 固定したときに断面 C の各鱪条の変位を, 断面 C を固定したとき に断面 Dの各鯺条の変位を同様に測定した. 各鱪条に荷重を加え たときの尾鱪全体の変位の仕方により弾性軸と考えられる鰙条を 推測した. 弾性軸に対忘する鯺条の変位量 $\delta$, 荷重 $P$, 固定断面と 測定断面との間の距離 $L$ を用い，片持ち梁に集中荷重を加えた場 合のたわみの基本式より, 尾鰭の測定区間の相当曲け剛性 $E I$ を式 (1)を用いて求めた.

$$
E I=\frac{P L^{3}}{3 \delta}
$$

但し， $E$ は固定断面と測定断面との間の平均ヤング率を表し，I は断面 2 次モーメントを表す。

相当曲け剛性から平均ヤング率を求めるために Fig.3 に示す尾 鯺の断面形状を考えた. 尾鰆の断面形状を半棈円, 四角形, 台形, そして三角形の組み合わせとし, 計算をする際には, 各領域の中 間の断面形状を用いた. その断面 2 次モーメントは次式に示す.

$$
\begin{aligned}
& I=\frac{\pi}{64} a^{3} c+\frac{1}{12} a^{3} d+\frac{1}{48} e\left\{(a-b)^{3}+4 b(a-b)^{2}\right. \\
& \left.+6 b^{2}(a-b)+4 b^{3}\right\}+\frac{1}{48} b^{3} f
\end{aligned}
$$

但し，a,b...f は，断面形状の各寸法を表す.

式 (1) と式 (2) より固定断面と測定断面との間の平均ヤング 率俚式（3）より求められる.

$$
E=\frac{P L^{3}}{3 \delta I}
$$

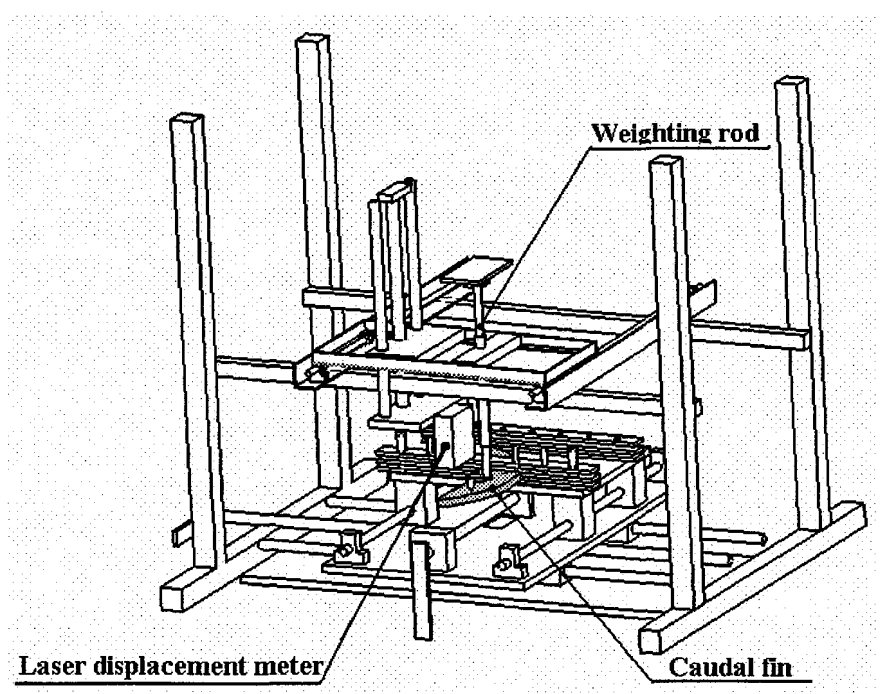

Fig.1 Schematic drawing of experimental apparatus 


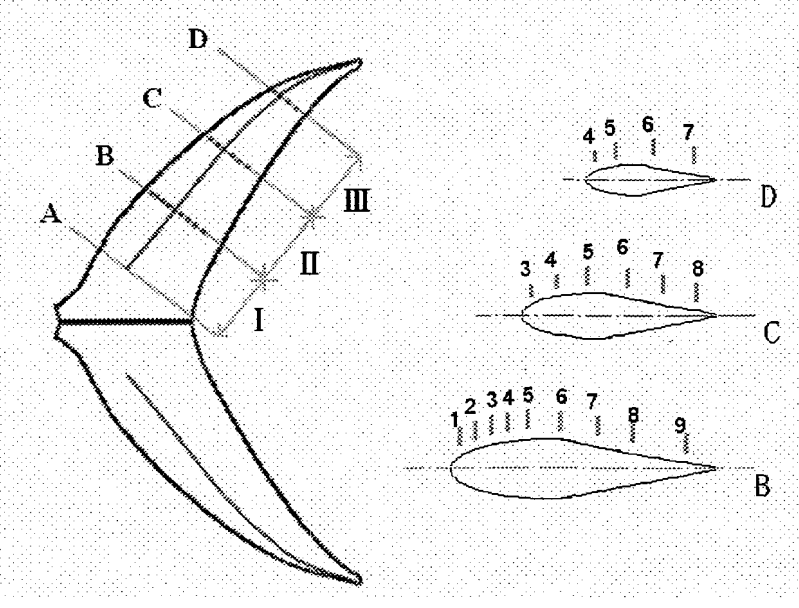

Fig. 2 Measuring points of caudal fin A,B,C are cross-sections for measuring bending displacement.

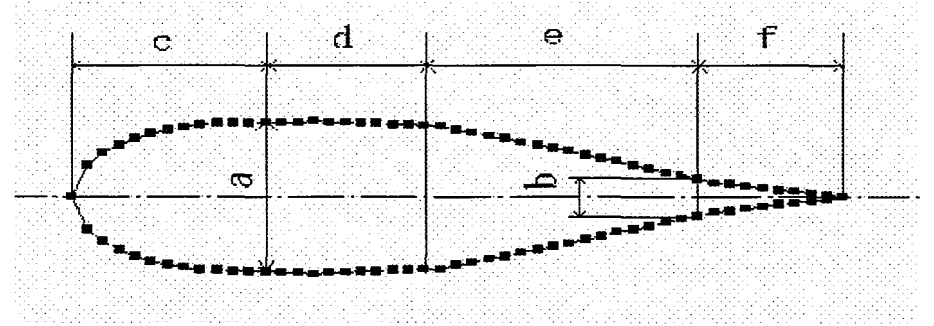

Fig.3 Cross-section of caudal fin model

\section{3. 実験結果および考察}

今回の実験で用いた 3 本の黒マグロの尾鰭の寸法を Table1 に示 す. 測定結果の一例として, No.1 の尾鮊について，固定断面 B, 測定断面 $\mathrm{C}$, 荷重を $10 \mathrm{~N}$ と, 荷重点を変化させたときの鯺条の 変位を Fig.4 に示す. 鱪条 5 に荷重を加えたとき，ねじりが起こ らず曲げ変位のみとなっていることから鱪条 5 が弾性軸であると 推測できる. 固定断面 $\mathrm{A}$ 測定断面 $\mathrm{B}$, 固定断面 C 測定断面 D と した場合にも同様の結果が得られた.

Fig.2 に示すように尾鰭を I ，II，IIIのように3つの領域に分け たとき，各領域の相当曲け岡性を Fig.5 に，また平均ヤング率を Fig.6に示す. 相当曲け剛性，平均ヤング率ともにその值は個体に よって異なるが，相当曲け剛性は翼端に近づくほど值が小さく， 平均ヤング率は值が大きくなった，つまり，翼端に近づくほど曲 がりやすいが，材質としては硬くなるということがわかった。こ れは，翼端に近づくと細く薄くなるために相当曲げ岡性は小さく なるが，コラーゲンなどの物質が少なくなり鱪条の割合が大きく なるために平均ヤング率が大きくなったと推測できる.

Table1 Dimension of caudal fin of blue fin tuna

\begin{tabular}{|c|c|c|}
\hline No. of Fin & Chord (mm) & Span (mm) \\
\hline 1 & 105 & 446 \\
\hline 2 & 105 & 440 \\
\hline 3 & 95 & 460 \\
\hline
\end{tabular}

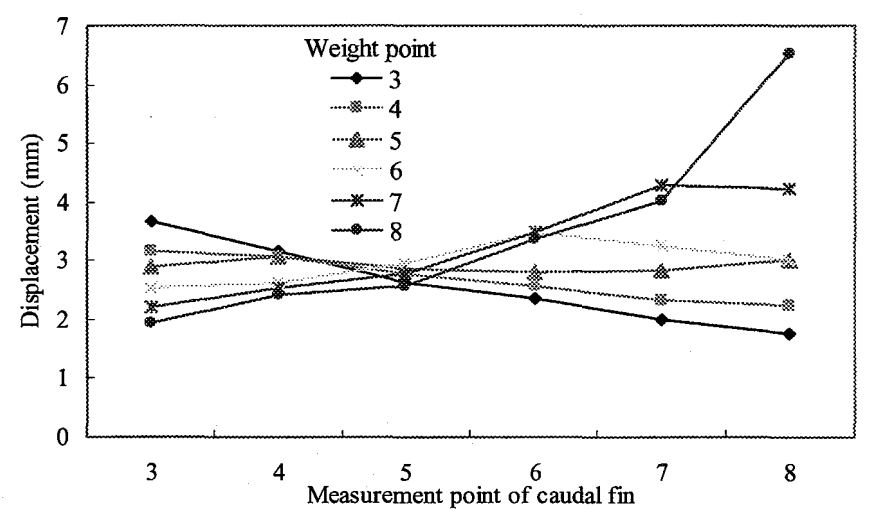

Fig.4 Displacement of fin ray in caudal fin

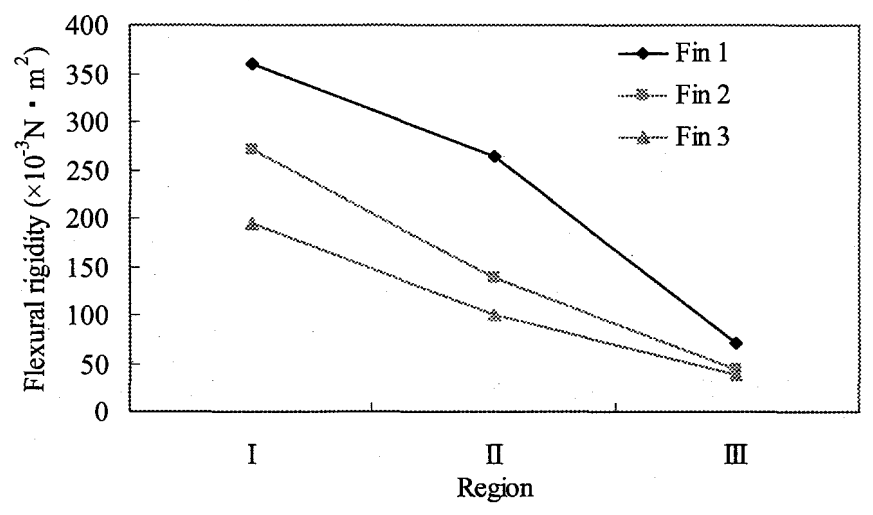

Fig.5 Flexural rigidity for regions $\mathrm{I}$, II, III of caudal fin of tuna

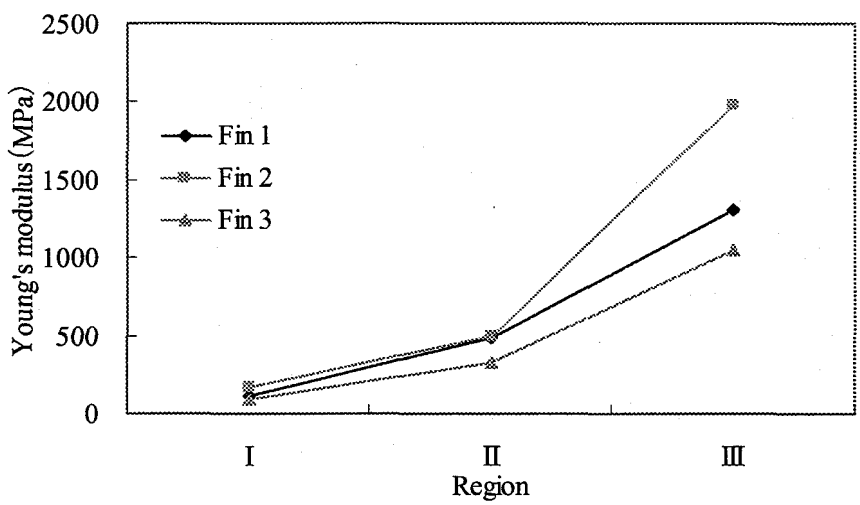

Fig.6 Young's modulus for regions I, II, III of caudal fin of tuna

\section{4. おわりに}

マグロの尾鰭の荷重による曲げ変位を測定し，相当曲げ岡性， 平均ヤング率を求めた．その結果，尾鯺は翼端に近づくほど曲が りやすいが材質としては硬くなるということがわかった. 今後, これらの結果を用いて，模型翼を作製し，翼挙動と推進性能との 関係を調べる予定である.

参考文献

1）龍広南，森川裕久，小林俊一：マグロの尾鯺の力学的特性，日 本機械学会第 13 回バイオエンジニアリング講演会論文集, No.00-35, 242-243, 2001. 